\title{
Building competitiveness and sustainability in real scenarios of Brazilian agriculture
}

\author{
Emilson França de Queiroz ${ }^{(1)}$
} (1)Embrapa Informação Tecnológica, Parque Estação Biológica, Avenida W3 Norte (Final), Edifício Sede, CEP $70770-901$ Brasília, DF, Brazil.
E-mail: emilson.queiroz@embrapa.br

\section{Introduction}

One of the main reasons for the fragility of agroecosystems, especially of the large-scale ones, such as the "soybean belt" and the "corn belt" in the United States, and of the ones with large areas cultivated with sugarcane, corn, pastures, soybean, wheat, and other crops in Brazil, with a high specialization level, is their low biological complexity, resulting from the small number of flora and fauna species that constitute them. Natural ecosystems, such as tropical or subtropical forests, savannas, and cerrados (Brazilian savanna), include a great number of animal and plant species, and, therefore, have a high biodiversity level. This biodiversity shows biological complexity, which is one of the main elements responsible for smoothing the impacts of climate variability, particularly those of hydrological origin, as well as the occurrence of disease and pest breakouts that threaten the animal and plant components of these natural ecosystems.

Therefore, in short, the large-scale agroecosystems are characterized by two types of fragilities, due to the reduction of biodiversity and their low biological complexity. On the one hand, one of these fragilities results from losses in the capacity of smoothing great climate variabilities, among which the main one is the amount and intensity of rainfall, including their adverse extremes to tropical and subtropical agriculture production, i.e., drought and floods. This is considered a fragility from the hydrologic point of view. On the other hand, the large-scale agroecosystems made up by a reduced number of species have a high density of susceptible hosts, which are the few cultivated species in comparison with the great number of species that are part of the natural ecosystem. This is a fragility from the health point of view.

The response strategy to these anthropogenic impacts, aiming at the competitiveness and the sustainability of the agroecosystems for the large-scale production of foodstuffs and food security, at national and international levels, necessarily requires knowledge, as well as Science \& Technology, focusing on Soil and Water Management and Conservation, and on the Management of Pests, Diseases and Invasive Species, in order to protect animal and plant health in agriculture. A third group of scientific and technological knowledge, indispensable for the whole performance and sustainability of agriculture, is related with the Management of Crops, Livestock, and Planted Forests. Finally, in highly mechanized agriculture and livestock, which is typical of large-scale agroecosystems, the fourth group of knowledge and technologies is considered the adequate Management of Machines, Implements, and Equipment, without which there may be great disturbances on soil attributes, which may affect the competitiveness and sustainability of agricultural production.

For the development of science and technology on plant and animal production, scientific knowledge on the most diverse areas of Science is important, among which are highlighted: Agricultural Sciences, Exact and Earth Sciences, Economic and Social Sciences, and Human and Animal Health Sciences. Of these areas of science, Soil Science is the main one related with this Thematic Issue.

\section{Repositories of Science \& Technology in Agriculture in the Last 50 Years}

It should be highlighted that the original scope of the Brazilian Journal of Agricultural Research (PAB), which completes 50 years of uninterrupted publication, has laid the groundwork and pointed out the necessary requirements to meet the demands, in scientific and technological terms, of the great groups of knowledge previously mentioned. Over time, 
through a retrogressive and objective observation, the reader was able to note with admiration that what was planned 50 years ago was appropiate to meet the demands over these years in a manner beyond expectation. Moreover, this production of knowledge supported the impressive growth and development of Brazilian agriculture, raising the interest of politicians, technicians, and scientists of different countries worldwide. In other words, the current success of Brazilian agriculture, is, as it should be, established on the great collection of scientific and technological production of Brazilian agricultural research, of which PAB is a small, but highly significant, sample. These traits can also be applied to a select group of Brazilian journals in areas related with agriculture, among which are: Bragantia, of Instituto Agronômico de Campinas, in the state of São Paulo; Arquivos do Instituto Biológico, also in the State of São Paulo; Scientia Agricola of Escola Superior de Agricultura Luiz de Queiroz (Esalq) of Universidade de São Paulo; Genetics and Molecular Biology of Sociedade Brasileira de Genética; Pesquisa Veterinária Brasileira of Colégio Brasileiro de Patologia Animal; Revista Brasileira de Ciência do Solo of Sociedade Brasileira de Ciência do Solo; Revista Brasileira de Zootecnia of Sociedade Brasileira de Zootecnia; Ciência Rural of Universidade Federal de Santa Maria; Horticultura Brasileira of Associação Brasileira de Horticultura; Tropical Plant Pathology of Sociedade Brasileira de Fitopatologia; Revista Brasileira de Entomologia of Sociedade Brasileira de Entomologia, just to mention a few of the first ones.

\section{Conjuncture and Challenges Presented in the International Year of Soils}

Social and Economic Development, one of the permanent and essential goals for any Nation, confers Science \& Technology one of its main motivating elements: the character of an interminable activity. Even though Science may already be developed in a certain country or worldwide, its disquietude or unconformity, as well as the demands of a healthy and vigorous society, continuously stimulates it to new challenges. As aforementioned, the demands over the last 50-60 years were met and, now, we are faced with new challenges, presented in the context of the International Year of Soils.
The $68^{\text {th }}$ United Nations (UN) General Assembly, in New York, adopted, in December 20, 2013, the $\mathrm{A} / \mathrm{RES} / 68 / 232$ resolution that declared 2015 as the International Year of Soils and designated the Food and Agriculture Organization (FAO) to implement it. From this resolution, several initiatives were carried out, among which is highlighted the elaboration and publication of the document "Estado Mundial del Recurso Suelo" (Estado mundial..., 2016), which is the first international evaluation on soils and related topics. This report is a result of structuring the activities that were attributed to the Intergovernmental Technical Panel on Soils (ITPS), the main organ to provide scientific and technical advice for the Global Soil Partnership (GSP), also from FAO. In this context, in Brazil, the decision No. 1942/2015 (TCU, 2015a) was published by the country's Federal Court of Accounts, referring to the operational audit done by SecexAmbiental, in order to evaluate aspects regarding the governance of nonurban soils and to prepare the respective report (TCU, 2015b).

In its report, ITPS presents four actions that it considers as priorities, which are transcribed here:

"1. Sustainable soil management can increase the supply of healthy food for the most food insecure among us. Specifically we should minimize further degradation of soils and restore the productivity of soils that are already degraded in those regions where people are most vulnerable.

2. The global stores of soil organic matter (e.g. SOC and soil organisms) should be stabilized or increased. Each nation should identify locally appropriate SOC-improving management practices and facilitate their implementation. They should also work towards a national-level goal of achieving a stable or positive net SOC balance.

3. Compelling evidence exists that humanity is close to the global limits for total fixation of nitrogen and regional limits for phosphorus use. Therefore we should act to stabilize or reduce global nitrogen $(\mathrm{N})$ and phosphorous $(\mathrm{P})$ fertilizer use while simultaneously increasing fertilizer use in regions of nutrient deficiency. Increasing the efficiency of $\mathrm{N}$ and $\mathrm{P}$ use by plants is a key requirement to achieve this goal.

4. The regional assessments in this report frequently base their evaluations on studies from the 1990s based on observations made in the $1980 \mathrm{~s}$ or earlier. We must improve our knowledge about the current state 
and trend in the condition of soil. An initial emphasis should be on improving observation systems to monitor our progress in achieving the three priorities outlined above."

Among these topics, the report discusses the relationships of soils with food security, water, climate, human health, and biodiversity. After approaching regional trends in soil conditions, at a continental level, briefly presented in Table 1, the report summarizes the global threats to soil functions and suggests seven political routes to face these challenges (Estado mundial..., 2016).

The ten threats are, in order of priority, at a global scale:

1. Soil erosion;

2. Soil organic carbon change;

3. Nutrient imbalance;

4. Salinization and sodification;

5. Soil sealing and land take (cities and industries);

6. Loss of soil biodiversity;

7. Soil contamination;

8. Soil acidification;

9. Soil compaction;

10. Waterlogging.
In addition, the report mentions the strategic stages of the action plans based on the pillars of the GSP, as follows:

$\sqrt{ }$ Great improvement on observations and forecast systems to determine when and how soil function is being affected (pillars 4 and 5);

$\sqrt{ }$ Implementation of sustainable soil management in large regions with urgent priorities where subsistence is vulnerable and highly dependent on subsistence agriculture (pillars 1, 2, and 3);

$\sqrt{ }$ Improvement in the management and development of more efficient agreements between organizations for the implementation of sustainable soil management (starting with the preparation of voluntary guidelines) (pillars 1 and 2);

$\sqrt{ }$ Mobilization of resources to train a new generation of soil specialists (pillars 1 to 4 ).

Finally, the document "Estado Mundial del Recurso Suelo" (Estado mundial..., 2016) establishes a historical perspective in its last paragraph, cited here in verbis:

"The International Year of Soils in 2015 will be remembered in the next decades as a year in which the challenges that are faced by soils worldwide were clearly articulated. We hope there is a substantial

Table 1. Summary of global and continental threats to soil functions.

\begin{tabular}{|c|c|c|c|c|c|c|c|}
\hline $\begin{array}{l}\text { Africa and south } \\
\text { of the Sahara }\end{array}$ & Asia & $\begin{array}{l}\text { Europe and } \\
\text { Eurasia }\end{array}$ & $\begin{array}{c}\text { Latin America and } \\
\text { the Caribbean }\end{array}$ & $\begin{array}{c}\text { East and North } \\
\text { Africa }\end{array}$ & $\begin{array}{l}\text { North } \\
\text { America }\end{array}$ & $\begin{array}{c}\text { Southwest } \\
\text { Pacific }\end{array}$ & Global \\
\hline Soil erosion & Soil erosion & $\begin{array}{l}\text { Soil sealing } \\
\text { and land take }\end{array}$ & Soil erosion & Soil erosion & Soil erosion & Soil acidification & Soil erosion \\
\hline $\begin{array}{l}\text { Organic carbon } \\
\text { change }\end{array}$ & $\begin{array}{l}\text { Organic carbon } \\
\text { change }\end{array}$ & $\begin{array}{l}\text { Salinization and } \\
\text { sodification }\end{array}$ & $\begin{array}{c}\text { Organic carbon } \\
\text { change }\end{array}$ & $\begin{array}{l}\text { Salinization and } \\
\text { sodification }\end{array}$ & Nutrient imbalance & Soil erosion & $\begin{array}{c}\text { Organic carbon } \\
\text { change }\end{array}$ \\
\hline $\begin{array}{l}\text { Nutrient } \\
\text { imbalance }\end{array}$ & $\begin{array}{l}\text { Salinization and } \\
\text { sodification }\end{array}$ & Contamination & $\begin{array}{l}\text { Salinization and } \\
\text { sodification }\end{array}$ & $\begin{array}{l}\text { Organic carbon } \\
\text { change }\end{array}$ & $\begin{array}{c}\text { Organic carbon } \\
\text { change }\end{array}$ & $\begin{array}{c}\text { Organic carbon } \\
\text { change }\end{array}$ & $\begin{array}{l}\text { Nutrient } \\
\text { imbalance }\end{array}$ \\
\hline $\begin{array}{l}\text { Loss of soil } \\
\text { biodiversity }\end{array}$ & $\begin{array}{l}\text { Nutrient } \\
\text { imbalance }\end{array}$ & $\begin{array}{c}\text { Organic carbon } \\
\text { change }\end{array}$ & $\begin{array}{l}\text { Loss of soil } \\
\text { biodiversity }\end{array}$ & Contamination & $\begin{array}{l}\text { Loss of soil } \\
\text { biodiversity }\end{array}$ & Nutrient imbalance & $\begin{array}{l}\text { Salinization and } \\
\text { sodification }\end{array}$ \\
\hline Soil acidification & Contamination & Nutrient imbalance & Compaction & $\begin{array}{l}\text { Sealing and } \\
\text { land take }\end{array}$ & Compaction & Compaction & $\begin{array}{l}\text { Soil sealing and } \\
\text { land take }\end{array}$ \\
\hline Waterlogging & $\begin{array}{l}\text { Soil sealing } \\
\text { and land take }\end{array}$ & Soil erosion & Waterlogging & Compaction & $\begin{array}{l}\text { Sealing and land } \\
\text { take }\end{array}$ & $\begin{array}{l}\text { Soil sealing and } \\
\text { capping }\end{array}$ & $\begin{array}{l}\text { Loss of soil } \\
\text { biodiversity }\end{array}$ \\
\hline Compaction & Soil acidification & $\begin{array}{l}\text { Loss of soil } \\
\text { biodiversity }\end{array}$ & Contamination & $\begin{array}{l}\text { Loss of soil } \\
\text { biodiversity }\end{array}$ & $\begin{array}{l}\text { Salinization and } \\
\text { sodification }\end{array}$ & Contamination & Contamination \\
\hline $\begin{array}{l}\text { Soil sealing and } \\
\text { land take }\end{array}$ & Compaction & Soil acidification & $\begin{array}{l}\text { Soil sealing and } \\
\text { land take }\end{array}$ & Soil acidification & Contamination & $\begin{array}{l}\text { Salinization and } \\
\text { sodification }\end{array}$ & Soil acidification \\
\hline $\begin{array}{l}\text { Soil } \\
\text { contamination }\end{array}$ & Waterlogging & Waterlogging & ---- & $\begin{array}{l}\text { Nutrient } \\
\text { imbalance }\end{array}$ & $\begin{array}{c}\text { Soil } \\
\text { acidification }\end{array}$ & $\begin{array}{l}\text { Loss of soil } \\
\text { biodiversity }\end{array}$ & Compaction \\
\hline ---- & $\begin{array}{l}\text { Loss of soil } \\
\text { biodiversity }\end{array}$ & Compaction & ---- & Waterlogging & Waterlogging & Waterlogging & Waterlogging \\
\hline
\end{tabular}

Source: Estado... (2016) 
progress in approaching the identified problems before the next report on the 'Status of Global Soil Resources' is published in 2020."

\section{Thematic Issue: "Soil as an Integrating Factor between Environmental Components and Agricultural Production"}

This Thematic Issue, under the title "Soil as an Integrating Factor between Environmental Components and Agricultural Production", was elaborated and published to be part of this context and to provide the authors with an additional opportunity of publishing their results in a set. Although this publication is only a sample that has no intention of representing all the efforts being carried out in Brazil on this topic, we hope it is a valuable contribution to increase the competitiveness and sustainability of Brazilian agriculture. It is rewarding to consider that, with this effort, we are contributing for these objectives and, modesty apart, are inserted in a global effort to promote the welfare of humankind. In Brazil, this effort is coordinated, stimulated and, in a great proportion, executed by governmental institutions, predominantly by several Universities and federal and state Research Institutes.

This great group of institutions also consists of benefactors and numerous nongovernmental organizations structured in Scientific Societies. In the specific case of Soil Science, it is adequate to mention, as an example, the highly scientific and technological action of the patriotic and traditional Brazilian Soil Science Society (SBCS), formed by a pleiad of eminent Brazilian scientists who are dedicated to the most diverse and intricate problems in the area.

This group, however, will be only realistically described when the private sector is also considered, whose contribution extends from teaching at college to research and technical assistance. Research by the private sector, as expected, predominantly produces protected knowledge in the areas of development and production of fertilizers and correctives, agricultural defensives, machines, implements and equipment, cultivars, clones and races, frequently articulated with marketing strategies and the corresponding technical assistance.

Therefore, besides being rewarding, the participation in the construction of basic knowledge for the operation of this whole set of actions and activities expresses the high level of social and environmental responsibilities of each professional, with different functions, who take part in this task.

This Thematic Issue is the result of a productive partnership between Embrapa Informação Tecnológica (SCT), Embrapa Solos (CNPS), Embrapa Agrobiologia (CNPAB), and Universidade Federal Rural do Rio de Janeiro (UFRRJ). The integrated action of Managers, Teachers, and Researchers of these institutions was one of the essential elements for the success of this initiative. First of all, the partnership promoted and increased the prestige of the Call of Papers for the Thematic Issue, which would not have been possible by an isolated action of SCT and PAB. This initial stimulus was strong and decisive enough to overcome the many difficulties that occur during the evaluation by peers of a publication of this dimension. We are sure that this collaboration will extend to the period after publishing, when efforts are made to promote its contents.

The elaboration and publication of this Thematic Issue was only possible by the competent, determined, and generous contribution of a large group of professionals, among who are: Authors, Scientific Advisors, Reviewers, Librarians, and Designers, mentioned throughout the issue or on the inside cover. Authors and Scientific Advisors will also be mentioned on the respective Annual List, which is routinely published in the last issue of the year.

This select group of scientists comes from numerous and prestigious Universities and Research Institutes of different regions in the country, which are traditional partners of Empresa Brasileira de Pesquisa Agropecuária (Embrapa) - under whose aegis is published Pesquisa Agropecuária Brasileira (PAB), which completes 50 years of uninterrupted publication this year. This Thematic Issue is part of the celebration of PAB's achievements.

\section{Final Considerations}

Science \& Technology are one of the main sectors that contribute to the formulation of response policies and strategies aiming at facing natural and anthropogenic disasters. This is a result of their capacity of accomplishing their mission of knowing the nature and the origin of adverse natural phenomena to human life, 
as well as of equating and solving the problems caused by their negative impacts. The Intergovernmental Panel on Climate Change (IPCC) is currently one of the most evident and emblematic examples of this responsibility of Science, which is shown by its structure, which comprises three interdependent Working Groups: Working Group I, "The Physical Science Basis"; Working Group II, "Climate Change Impacts, Adaptation and Vulnerability"; and Working Group III, "Mitigation of Climate Change"; besides the "Task Force on National Greenhouse Gas Inventories".

Even though this triad is not always explicit when facing issues related with soil use and conservation, it is an approach that can be very efficient and effective when the contribution of Science \& Technology is analyzed. In fact, the results of Science \& Technology, at national and international levels, are those producing: 1) the knowledge of the natural soil conditions prevailing in the natural ecosystems; 2) the knowledge of the impacts of human intervention and actions when natural ecosystems are replaced by anthropogenic ones, either urban or agricultural; 3) the basic knowledge from which policies, strategies, and response actions to these impacts are formulated.

Therefore, effectively, scientific and technological production and their results are essential and indispensable elements for the formulation of response strategies to the inescapable anthropogenic interventions in the natural environment, as well as to the posterior use and conservation of soils and of other environmental components.

In the last 50 years, this mission was accomplished in the real world, with its several environmental, economical, and social variables, as well as with those of constitutional and legal origins. The competitiveness and sustainability of Brazilian agriculture were constructed and guaranteed in the real scenarios at national and international levels. Now, the path is open to conquer the new challenges largely addressed during the International Year of Soils.

The path is also open for the elaboration of critical, review, and scientific and technical papers that make explicit and confirm the facts observed and reported here, and that consider the main advances in the various areas of Agricultural Sciences in the last 5060 years, especially if they are related with what was incorporated in the production processes of Brazilian agriculture. In this sense, Gomes et al. (2016) presents and applies a methodology to carry out such analysis in the work titled "Agricultura mundial: evolução, avanços e desafios", which can be considered a starting point for this type of analysis.

\section{Acknowledgments}

Now, I would like to thank, in the name of the Coordinating Commission and of all of PAB's team, the daily support we received from the General Manager of Embrapa Informação Tecnológica, Dr. Selma Lúcia Lira Beltrão, as well as from the Assistant Manager of Editorial Projects and the Assistant Manager of Administration, respectively, Dr. Lucilene Maria de Andrade and Dr. Marlene de Souza Costa de França.

Special thanks are addressed to Dr. Ladislau Martin Neto and to Dr. Waldyr Stumpf Junior, Executive Directors of Embrapa, as well as to Dr. Maurício Antônio Lopes and to Dr. Gerson Soares Alves Barreto, respectively President and Chief of the President's Office of Embrapa, who individually or together guaranteed the operational sustainability of this journal, keeping a tradition that persists since the first moments of PAB's creation, when the Agricultural Engineers Dr. Ady Raul da Silva and Dr. Roberto Meireles de Miranda - Directors (at that time) of the then National Department of Agricultural Research and Experimentation (DNPEA) - took the decision of creating and supporting it since 1965-1966.

The elaboration of a document of this stature only happens with a great effort of all its builders, in order to overcome the expected or unexpected vicissitudes and to come to a good term, which is this Thematic Issue.

I call upon Luiz de Camões, in his masterly oeuvre "Os Lusíadas", book ("canto") VI, stanzas 92 and 93, which describe the arrival in India after several vicissitudes in the sea and land, when the hero thanks God for His great mercy:

92 Já a manhã clara dava nos outeiros Por onde o Ganges murmurando soa, Quando da celsa gávea os marinheiros Enxergaram terra alta, pela proa. Já fora dos tormentos e dos primeiros Mares, o temor vão do peito voa. Disse alegre o piloto Melindano; “Terra é de Calecu, se não me engano; 
93

Esta é, por certo, a terra que buscais Da verdadeira Índia, que aparece; E, se do mundo mais não desejais, Vosso trabalho longo aqui fenece." Sofrer aqui não pôde o Gama mais, De ledo em ver que a terra se conhece: Os joelhos no chão, as mãos ao Céu, A mercê grande a Deus agradeceu.

\section{References}

ESTADO mundial del recurso suelo: resumen técnico. Roma: FAO, 2016. 79p.

GOMES M. P.; GRÜNDLING R. D. P.; CONTINI E.; VIEIRA JÚNIOR P. A. Agricultura mundial: evolução, avanços e novos desafios. In: Desafios do cerrado: como sustentar a expansão da produção com produtividade e competitividade - Cuiabá:
Associação Mato-grossense dos Produtores de Algodão, 2016. p. 11-44.

TCU. TRIBUNAL DE CONTAS DA UNIÃO. TC 011.713/20151. 2015a. Relatório de auditoria. Disponível em: $<$ http://portal3. tcu.gov.br/portal/page/portal/TCU/imprensa/noticias/noticias arquivos/011.713-2015-1\%20MAPA \%20E\%20MMA\%20 solos\%20comp.pdf $>$. Acesso em: 27 set. 2016.

TCU. TRIBUNAL DE CONTAS DA UNIÃO. Acórdão 1942, de 5 de agosto de 2015. 2015b. Disponível em: $<$ https://contas.tcu.gov.br/juris/Web/Juris/ConsultarTextual2/ Jurisprudencia.faces? colegiado $=$ PLENARIO\&numeroAcordao $=$ 1942\&anoAcordao=2015 $>$. Acesso em: 28 set. 2016.UNITED NATIONS. General Assembly. Resolution adopted by the General Assembly on 20 December 2013 [on the report of the Second Committee (A/68/444)]. A/RES/68/232. World Soil Day and International Year of Soils. Disponível em: $<$ http://www.un.org/ en/ga/search/view_doc.asp?symbol=A/RES/68/232>. Acesso em: 27 set. 2016. 